\title{
Protein reserves and muscle constituents of protein-depleted and repleted cocks*
}

\author{
By JOHN H. ASHLEY AND HANS FISHER \\ Nutrition Laboratories, Department of Animal Sciences, \\ Rutgers-The State University, New Brunswick, New fersey, USA \\ (Received 20 December 1966--Accepted 6 March 1967 )
}

\begin{abstract}
I. Body-weight changes and nitrogen balance were studied, together with the concentration of various nitrogenous muscle components, in adult cocks before and after a 6 -day period on a $\mathrm{N}$-free diet and again after a $\mathbf{1 6}$-day repletion period on diets supplying various amounts and types of dietary $\mathrm{N}$.

2. In the first experiment a comparison was made during the repletion period between a fish-protein supplement and a supplement of glycine + glutamic acid added to an essential amino acid mixture.

3. During the depletion period the muscle concentration of RNA, DNA and of two transaminase enzymes decreased significantly; during the repletion period these components increased again significantly, and usually to levels greater than the pre-depletion concentration. There were no differences in these responses obtained during repletion with the two $\mathrm{N}$ supplements, although the cocks given the glycine-glutamic acid supplement differed from those receiving fish protein in being in negative $\mathrm{N}$ balance and in losing body-weight during the repletion period.

4. In the second experiment one group of depleted cocks was given an essential amino acid mixture alone as the dietary $N$ source and a second group this mixture supplemented by aspartic acid.

5. A decrease in RNA and in the transaminase enzymes during depletion was followed by a significant increase during repletion, but the increase was greater for the group receiving the aspartic acid than for that receiving only the essential amino acid mixture.

6. It was concluded that adding non-essential amino acids to a maintenance mixture of essential amino acids will permit greater repletion in mature cocks.

7. The fluctuations in concentration of RNA and of certain enzymes with dietary protein supply may well be a controlling factor in the regulation of $\mathrm{N}$ losses and accretions during protein deficiency and sufficiency.
\end{abstract}

8. The relative constancy of muscle DNA in contrast to the fluctuations in other nitrogenous muscle constituents provides additional support for the concept of protein reserves.

The amount of body nitrogen loss in adult cocks on a protein-free diet beyond which repletion does not occur with a supplement of non-essential amino acids to a maintenance mixture of essential amino acids has been regarded as a measure of the size of the protein reserve pool (Wessels \& Fisher, 1965). This estimate of the magnitu de of the body's protein reserves was based upon the observations of Shapiro \& Fisher (1962) that partial repletion of body $\mathrm{N}$ stores could be attained by non-essential amino acid $\mathrm{N}$ in adult cocks depleted to the endogenous level of $\mathrm{N}$ excretion. Logical support for these experimental findings may be derived from a study by Basak (I $95^{8}$ ). Basak showed that the $\mathrm{N}$ losses of human subjects kept for a short period on a protein-free diet were primarily non-protein in origin and represented about $6 \%$ of the total body $\mathrm{N}$ of human adults on a normal diet. This quantity is similar to the estimated magnitu de of

* Paper of the Journal Series, New Jersey Agricultural Experiment Station, New Brunswick. Supported in part by Grant-in-Aid from the National Science Foundation. 
$\mathrm{N}$ stores in the adult cock $(6.9 \%$ of body $\mathrm{N})$ as measured by the depletion technique of Wessels \& Fisher (1965).

Additional support for estimating the magnitude of protein reserves by protein depletion, followed by repletion with supplements of non-essential amino acids, has also been obtained in this laboratory. When adult human subjects, previously on a diet inadequate in either protein or an essential amino acid, were given a supplement of gelatin or a mixture of non-essential amino acids they retained significant amounts of $\mathrm{N}$ from these poor-quality $\mathrm{N}$ sources (Fisher, Brush, Griminger \& Sostman, 1965). Kies, Williams \& Fox (1965) also showed a significant improvement in $\mathrm{N}$ retention of adult human subjects when non-essential amino acid $\mathrm{N}$ was added to a low-protein cereal diet.

Although the results of the studies cited all show considerable $\mathrm{N}$ retention from supplementation with sources of non-essential amino acid $\mathrm{N}$, they are, nevertheless, incomplete in that they do not provide clear evidence that the retained $\mathrm{N}$ has been, or could be, utilized for the synthesis of previously depleted nitrogenous body components. Wessels \& Fisher $(1965)$ were able to show only a limited repletion of nitrogenous liver components in repleted cocks that were in positive $\mathrm{N}$ balance.

Allison \& Wannemacher ( 1965$)$ have shown that muscle contributed the major portion of the $\mathrm{N}$ loss during protein depletion. In view of this observation we investigated the concentration of muscle deoxyribonucleic acid (DNA), ribonucleic acid (RNA), and the enzymes glutamic-oxaloacetic transaminase (GOT) and glutamicpyruvic transaminase (GPT) in protein-depleted and variously repleted cocks. These observations were expected to yield valuable information concerning the state of protein reserves and their dietary nitrogenous origin. The results provide new evidence for the existence of reserves and suggest that protein reserves might be considered not only as a quantity of labile body protein or amino acids, but also in terms of changes in rate of the processes involving protein metabolism.

\section{EXPERIMENTAL}

Two experiments, involving a total of forty-eight cocks, were carried out. The care and maintenance of the birds, the depletion and repletion procedures, as well as the composition of the basal diets used, were similar to those previously described (Wessels \& Fisher, 1965).

$$
\text { Expt I }
$$

Thirty I I-month-old White Leghorn cocks were depleted of protein by 6 days on a protein-free diet and lost between $4 \%$ and $6 \%$ of their initial body N, i.e. the amount considered by Wessels \& Fisher ( 1965 ) to be equivalent to the protein reserves of the cocks. During a 16-day repletion period the birds were given diets that supplied daily $280 \mathrm{mg} \mathrm{N} / \mathrm{kg}$ body-weight, an amount previously shown to be adequate for the maintenance of non-depleted adult cocks (Leveille \& Fisher, 1958). Two repletion diets were used and both contained a mixture of essential amino acids which daily provided I $5 \mathrm{mg} \mathrm{N} / \mathrm{kg}$ body-weight (Shapiro \& Fisher, 1962). The remainder of the amino acids, or $165 \mathrm{mg} \mathrm{N}$, in one diet was supplied from fish meal, and in the other diet by a mixture of equal amounts of glycine and glutamic acid. Biopsies were 
carried out on six of the thirty cocks before the start of the depletion period, on eight different cocks at the end of the 6-day protein-depletion period, and on all the cocks given the repletion diets at the end of the repletion period. A number of cocks were eliminated during the study because of food refusal or excessive $\mathrm{N}$ loss during depletion.

Biopsy. Feathers between the clavicle and sternum on both sides of the bird were removed and stored for $\mathrm{N}$ determination. The skin was then anaesthetized locally, with $\mathrm{I} \mathrm{ml}$ of a $\mathrm{I} \%(\mathrm{w} / \mathrm{v})$ procaine hydrochloride solution, and then cut, and drawn aside. Two $\mathrm{ml}$ of this solution were then injected into the muscle before the removal of $6-9 \mathrm{~g}$ of wet tissue. This tissue was stored in covered polyethylene beakers packed in ice until analysed. The skin flaps were drawn together and, as required, secured in position with $9 \mathrm{~mm}$ wound clips. The operation resulted in negligible loss of blood and no bird was lost through subsequent infection or reopening of wounds.

Analytical procedure. The $\mathrm{N}$ content of the muscle tissue, ground feathers, and excreta was obtained by semi-microKjeldahl digestion ( $100 \mathrm{ml}$ flasks), followed by the colorimetric determination of the ammonium ion in the digest with sodium phenate and sodium hypochlorite on the AutoAnalyzer (Ferrari, 1960). Carcasses were not analysed for their $\mathrm{N}$ content; instead, conversion factors based on body-weight were used from the results of Summers \& Fisher ( 1962 ) in order to express the $\mathrm{N}$ loss during depletion as a percentage of that present in the body of the non-depleted bird. The muscle tissue was cleaned of superficial connective tissue and weighed wet. Half of this tissue was dried in a forced-draught oven at $30^{\circ}$ in order to provide material for $\mathrm{N}$ determination and to determine the moisture content of the sample. A $30 \%$ homogenate of the remaining muscle was prepared in a mechanical tissue grinder using cold $0.9 \%(\mathrm{w} / \mathrm{v})$ saline solution. DNA and RNA were determined on portions of this homogenate by methods previously described in detail (Wessels $\&$ Fisher, 1965). The enzymes GOT and GPT were also determined in suitably diluted portions of the original homogenate by the method described by the Sigma Chemical Co., St Louis, Missouri (1959). The excreta were collected on alternate days; feathers in the excreta were carefully removed, stored for separate analysis, and then homogenized with water and analysed for $\mathrm{N}$ as previously described.

\section{Expt 2}

In this experiment eighteen 9-month-old cocks were depleted of protein by 6 days on a protein-free diet and then repleted for 16 days. Biopsies were carried out on six cocks before the depletion period, and on the ten remaining birds after both the depletion and the repletion period. The birds that underwent post-depletion biopsy were divided into two groups, one of six birds and one of four, and given the following repletion diets: the four-bird group received only the essential amino acid mixture that provided daily I $5 \mathrm{mg} \mathrm{N} / \mathrm{kg}$ body-weight; the six-bird group received a diet that supplied $280 \mathrm{mg} \mathrm{N} / \mathrm{kg}$ body-weight, I $_{5} \mathrm{mg}$ of which was derived from an essential amino acid mixture, and $165 \mathrm{mg}$ from L-aspartic acid. The analytical procedures for this experiment were the same as those described for Expt $\mathrm{r}$. Two birds were eliminated before the start of the repletion period because of excessive $\mathrm{N}$ loss during depletion. 


\section{RESULTS}

Expt $\mathbf{I}$

During protein depletion the birds that underwent biopsy lost less body-weight and excreted less $\mathrm{N}$ than the normal cocks (Table $\mathrm{I}$ ), but the differences were not statistically significant, nor were similar results observed in other studies unrelated to the present report (Ashley, I966). During repletion (Table 2) the cocks receiving the

Table I. Expt $\mathrm{I}$ : mean values with their standard errors for body-weight changes and nitrogen losses of Leghorn cocks that underwent biopsy and for normal cocks depleted for 6 days on a protein-free diet

(Figures in parentheses are the numbers of birds)

\begin{tabular}{|c|c|c|}
\hline Measurement & $\begin{array}{c}\text { Cocks that } \\
\text { underwent biopsy } \\
(6)\end{array}$ & $\begin{array}{c}\text { Normal cocks } \\
(24)\end{array}$ \\
\hline \multicolumn{3}{|l|}{ Body-weight (g): } \\
\hline Initial & $2442 \pm 43$ & $235 I \pm 2 I$ \\
\hline Final & $2059 \pm 53$ & $1849 \pm 40$ \\
\hline$\Delta$ & $-383 \pm 47$ & $-502 \pm 39$ \\
\hline \multicolumn{3}{|l|}{$N$ loss: } \\
\hline In excreta ( $\mathrm{g} / \mathrm{bird})$ & $4.53 \pm 0.42$ & $7.03 \pm 0.80$ \\
\hline In feathers ( $\mathrm{g} / \mathrm{bird})$ & $0.96 \pm 0.16^{*}$ & $0.11 \pm 0.02$ \\
\hline In biopsy tissue (g/bird) & $0.3^{1} \pm 0.03$ & - \\
\hline Total: g/bird & $5.80 \pm 0.34$ & $7 \cdot 14 \pm 0.80$ \\
\hline as $\%$ initial body $\mathrm{N}+$ & $3.77 \pm 0.27$ & $4.79 \pm 0.54$ \\
\hline
\end{tabular}

Table 2. Expt I: mean values with their standard errors for body-weight changes and nitrogen intakes and losses of Leghorn cocks during a 16 -day repletion period on two diets with different $N$ supplements

(Figures in parentheses are the numbers of birds)

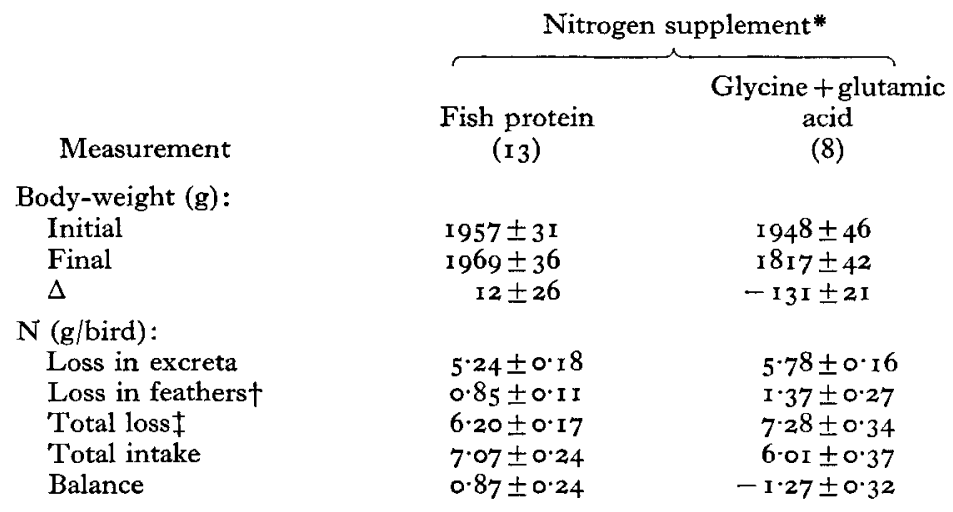

* Provided $165 \mathrm{mg} \mathrm{N} / \mathrm{kg}$ body-weight and was added to the basal diet which suplied $\mathrm{I} 5 \mathrm{mg} \mathrm{N}$ from essential amino acids per $\mathrm{kg}$ body-weight daily.

$\uparrow$ Most of the feathers were removed during biopsy.

$\mp$ The total loss includes, in addition to excreta and feather $\mathrm{N}$, a small amount of muscle $\mathrm{N}$ from cocks that underwent biopsy. 
essential amino acid mixture with the fish-protein supplement maintained their body-weight, whereas those with the glycine + glutamic acid $\mathrm{N}$ supplement continued to lose body-weight and were in negative $\mathrm{N}$ balance over the $\mathrm{I} 6$-day experimental period. The differences between the two groups were highly significant $(P<0.005)$. The considerable quantity of feather $\mathrm{N}$ lost during the repletion period on both diets (Table 2) should be especially noted, since in this laboratory it had not previously (Wessels \& Fisher, 1965) been included in the total $\mathrm{N}$ balance; on the basis of the present results it is obviously of considerable magnitude.

Table 3. Expt I : mean muscle nitrogen components with their standard errors of Leghorn cocks before and after a 6-day protein-depletion regimen and after a 16-day repletion period with different $N$ supplements

(Figures in parentheses are the numbers of birds)

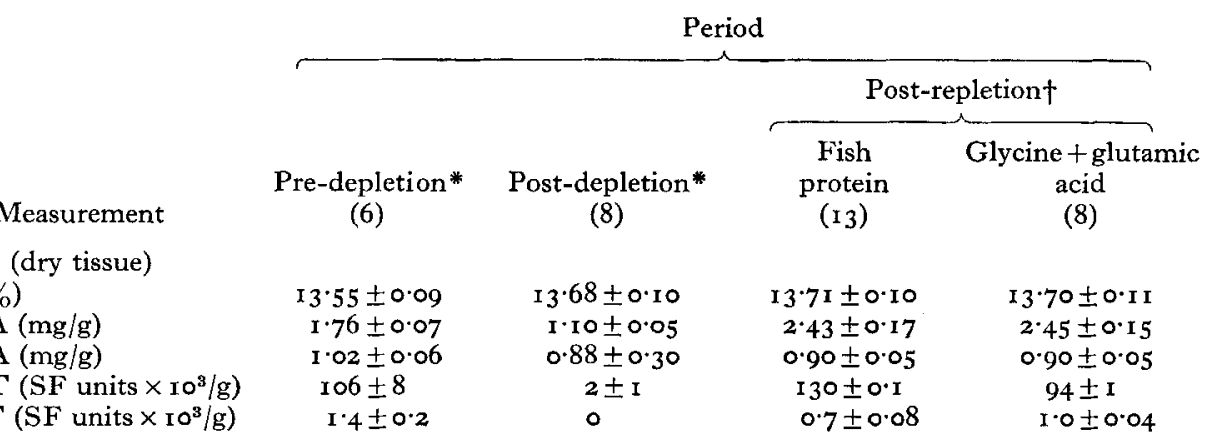

RNA, ribonucleic acid; DNA, deoxyribonucleic acid; GOT, glutamic-oxaloacetic transaminase; GPT, glutamic-pyruvic transaminase; SF, Sigma-Frankel units (Sigma Chemical Co., St Louis, Missouri, 1959).

* With the exception of muscle $\mathrm{N}$, all analyses were carried out in duplicate on tissue from each cock; muscle $\mathrm{N}$ was determined in triplicate.

$\uparrow$ Muscle $\mathrm{N}$ was determined in triplicate on tissue from each cock; all other analyses were carried out in duplicate on pooled tissue from several cocks.

Table 3 presents the major results of the present study. The muscle $\mathrm{N}$ content expressed on a dry basis did not change between the post-depletion and post-repletion periods. Following depletion there was a decrease in DNA concentration $(P<0.05)$. The RNA content of muscle decreased signicantly $(P<0.001)$ during depletion and increased again $(P<0.001)$ after repletion. The post-repletion values were also greater than the pre-depletion values. This was particularly interesting in view of the absence of change in total muscle $\mathrm{N}$ during the post-repletion period. It is of further interest that no differences were found, in the post-repletion values for RNA, between the cocks given the supplement of fish and those given the supplement of glycine+ glutamic acid.

The concentration of both the GO'T and GPT enzymes fell significantly $(P<0.00 \mathrm{I})$ during depletion and rose again $(P<0.001)$ after repletion. For the GOT enzyme the post-repletion concentrations were considerably higher than the pre-depletion values. Again, as for the RNA concentrations, the cocks given the glycine + glutamic 
acid $\mathrm{N}$ supplement were as efficient in re-establishing pre-depletion levels of the enzymes as were the birds given the fish-protein supplement.

The body-weight changes as well as the $\mathrm{N}$ balance results of Expt I suggested that the fish-protein supplement was superior to the glycine + glutamic acid $\mathrm{N}$ supplement and that the latter supplement would not permit adequate repletion. Since, however, the concentration of muscle RNA, GOT, and GPT from cocks given the glycine + glutamic acid $\mathrm{N}$ supplement indicated full repletion, following a sharp decrease during prior depletion, it was necessary to ascertain to what extent, if any, the nonessential amino acid supplement was contributing to the observed repletion results.

Table 4. Expt 2: mean values with their standard errors for body-weight changes and nitrogen losses of biopsied and normal Leghorn cocks during a 6-day depletion period on a protein-free diet

(Figures in parentheses are the numbers of birds)

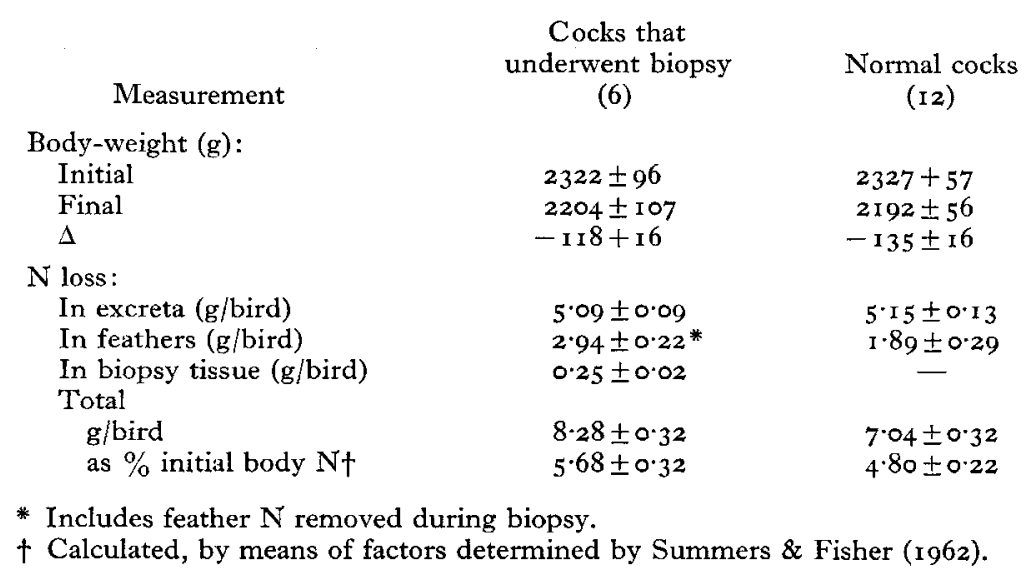

Expt 2

Expt 2 was designed to compare two groups of cocks: one group received only the essential amino acid maintenance mixture that supplied I $5 \mathrm{mg} \mathrm{N} / \mathrm{kg}$ body-weight daily and the other $280 \mathrm{mg} \mathrm{N} / \mathrm{kg}$ body-weight daily, including a non-essential amino acid $\mathrm{N}$ supplement (aspartic acid).

Table 4 shows the body-weight changes as well as the $\mathrm{N}$ losses of six cocks that underwent biopsy and of twelve normal cocks during a 6-day protein-depletion regimen. The weights and amounts of body $\mathrm{N}$ lost in the two groups were essentially similar. The considerable percentage of $\mathrm{N}$ which feather loss contributed to total body $\mathrm{N}$ loss during a relatively short 6-day protein-depletion period should be especially noted.

During the repletion period (Table 5) the cocks receiving only the essential amino acid mixture lost three times as much body-weight as was lost by the birds getting the additional aspartic acid, a significant difference $(P<0.05)$, and significantly more body N. The cocks for which results are given in Table 5 came from the group of twelve normal birds (Table 4), since the six cocks that underwent biopsy before 
Table 5. Expt 2: mean values with their standard errors for body-weight changes and nitrogen intakes and losses of Leghorn cocks during a $\mathrm{I} 6$-day repletion period on two diets with different amounts and source of dietary nitrogen

(Figures in parentheses are the numbers of birds)

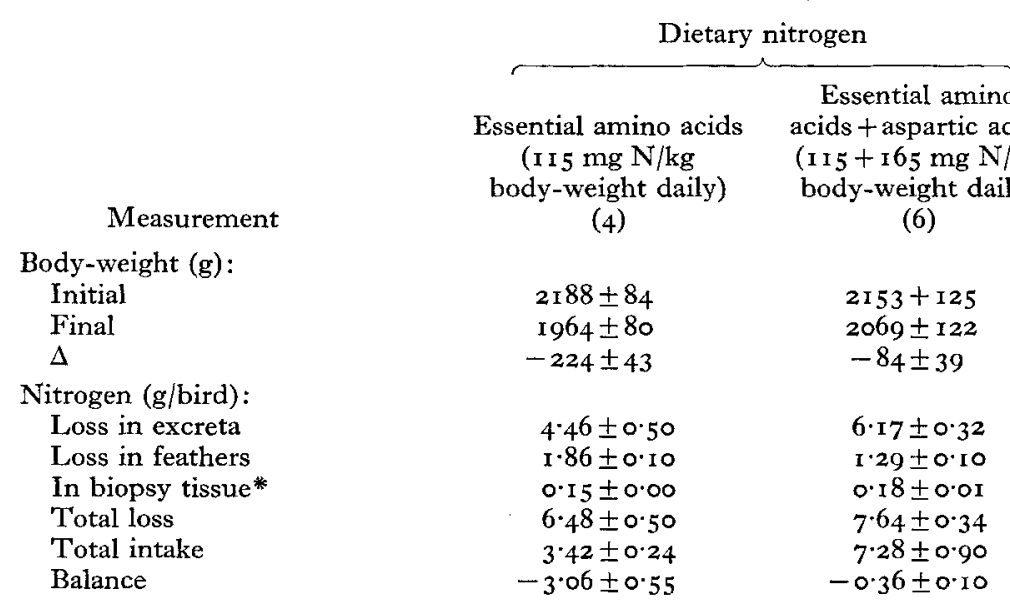

* All cocks underwent biopsy at the start of the repletion period.

Table 6. Expt 2: mean muscle nitrogen components with their standard errors of Leghorn cocks before and after a 6-day protein-depletion regimen and after a 16 -day repletion period with different amounts and source of dietary $N$

(Figures in parentheses are the numbers of birds)

\begin{tabular}{|c|c|c|c|c|c|}
\hline & \multicolumn{5}{|c|}{ Period } \\
\hline & & & & \multicolumn{2}{|c|}{ Post-repletion } \\
\hline asurement* & $\begin{array}{c}\text { Pre- } \\
\text { depletion } \dagger \\
(6)\end{array}$ & $\begin{array}{l}\text { Post-de } \\
\text { (4) }\end{array}$ & pletion $\downarrow$ & $\begin{array}{c}\text { Essential } \\
\text { amino } \\
\text { acids } \\
\text { (115 mg } \\
\text { N/kg } \\
\text { body-weight } \\
\text { daily) } \\
\text { (4) }\end{array}$ & $\begin{array}{c}\text { Essential } \\
\text { amino } \\
\text { acids + } \\
\text { aspartic } \\
\text { acid } \\
\text { (1 } 5+{ }^{2} 65 \\
\mathrm{mg} \mathrm{N} / \mathrm{kg} \\
\text { body-weight } \\
\text { daily } \\
(6)\end{array}$ \\
\hline suej. & & & & & \\
\hline $\begin{array}{l}\mathrm{mg} / \mathrm{g}) \\
(\mathrm{mg} / \mathrm{g}) \\
\left.\mathrm{SF} \text { units } \times 10^{3} / \mathrm{g}\right) \\
\left.\mathrm{SF} \text { units } \times 10^{3} / \mathrm{g}\right)\end{array}$ & $\begin{array}{c}13.28 \pm 0.08 \\
1.90 \pm 0.19 \\
0.94 \pm 0.10 \\
117 \pm 12 \\
0.6 \pm 0.2\end{array}$ & $\begin{array}{c}12.94 \pm 0.02 \\
1.35 \pm 0.10 \\
0.98 \pm 0.13 \\
\text { II } \pm 7 \\
0.6 \pm 0.3\end{array}$ & $\begin{array}{c}13.00 \pm 0.10 \\
1.25 \pm 0.08 \\
0.89 \pm 0.09 \\
25 \pm 5 \\
0.3 \pm 0.1\end{array}$ & $\begin{array}{l}12.52 \pm 0.22 \\
2.06 \pm 0.24 \\
0.95 \pm 0.15 \\
155 \pm 8 \\
0.6 \pm 0.4\end{array}$ & $\begin{array}{c}13.12 \pm 0.07 \\
2.51 \pm 0.19 \\
0.94 \pm 0.11 \\
180 \pm 4 \\
1.3 \pm 0.4\end{array}$ \\
\hline
\end{tabular}

Muscle (dry tissue):

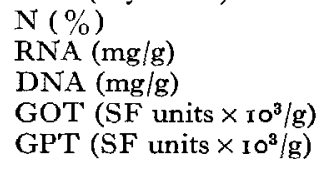

RNA, ribonucleic acid; DNA, deoxyribonucleic acid; GOT, glutamic-oxaloacetic transaminase; GPT, glutamic-pyruvic transaminase; SF, Sigma-Frankel units (Sigma Chemical Co., St Louis, Missouri, 1959).

* With the exception of muscle $\mathrm{N}$, all analyses were carried out in duplicate on tissue from each cock; muscle $\mathrm{N}$ was determined in triplicate.

+ Pre-depletion biopsies were carried out on a separate group of cocks from those repleted on the two different diets.

$\ddagger$ The two subgroups under this heading represent the same birds as given for the post-repletion period. 
depletion could not undergo it again after the depletion period. Thus, this experiment was continued with the normal cocks alone, and the six cocks that underwent biopsy before depletion served as reference for the evaluation of the muscle $\mathrm{N}$ components.

The muscle analyses (Table 6) showed a small decrease in $\mathrm{N}$ content during depletion. In this experiment there was no effect on muscle DNA content during any period of protein depletion or repletion. As in the first experiment, however, RNA and the GOT and GPT enzyme concentrations fell significantly $(P<0.001)$ following protein depletion, although the concentration of the two enzymes was higher following depletion than it was during the first experiment. During repletion, levels of RNA and of both enzymes regained the pre-depletion concentrations, GOT concentration being significantly greater $(P<0.02)$ in the cocks given the additional aspartic acid supplement than in those given only the mixture of essential amino acids. The differences in RNA and GPT levels between the two groups of cocks were in the same direction as those for GOT, but were not significant. During repletion the percentage of muscle $\mathrm{N}$ for the cocks receiving only the mixture of essential amino acids was significantly lower $(P<0.025)$ than before depletion and also significantly lower than that of the cocks receiving the additional aspartic acid.

\section{DISCUSSION}

We have previously defined the body protein reserves as the amount of body $\mathrm{N}$ loss on a protein-free diet beyond which repletion does not occur with a supplement of non-essential amino acids to a maintenance mixture of essential amino acids (Wessels $\&$ Fisher, 1965$)$. It seems reasonable to expect shifts in the body's protein reserves to represent changes within cells rather than changes in the number of cells. Although there was a decrease in muscle DNA concentration during depletion in Expt I, this observation was not repeated in the second experiment and might have resulted from incomplete DNA extraction (a hand-grinder, rather than the mechanical tissue grinder was used for this extraction). The relative constancy of DNA with the marked concomitant decrease in RNA and transaminase enzymes on depletion, followed by an increased concentration on repletion suggests that the cell constituents and not the number of cells varied with depletion or repletion of protein reserves in this study. If this reasoning is correct, it follows that the point at which DNA depletion begins should correspond to the point of total exhaustion of protein reserves or approximately $7 \%$ of body $\mathrm{N}$ based on our earlier work (Wessels $\&$ Fisher, 1965). In turn, if this assumption holds true it should be feasible to determine more precisely sites of protein reserves within the body based on changes in DNA concentration of different organs and tissues.

Our observations demonstrate that gross body changes, as expressed by $\mathrm{N}$ balance and body-weight, do not adequately represent the metabolic behaviour of the cocks during protein depletion and repletion. Although in both experiments the cocks receiving non-essential amino acids in addition to the essential amino acids failed to regain the body $\mathrm{N}$ (including that shed in feathers) which had been lost during the protein-depletion period, their muscle $\mathrm{N}$ constituents, as exemplified by RNA and 
two transaminase enzymes, were repleted to concentrations as high as or higher than those before the start of depletion. It is not known whether or not the rate of loss of feathers was higher than normal during the depletion period.

This study also suggests that the non-essential amino acid supplement was beneficial during repletion since in the cocks receiving the essential amino acid mixture alone, in comparison with those receiving additional aspartic acid, concentrations of muscle $\mathrm{N}$ and of GOT were significantly lower. For the other components studied the same trend prevailed. Furthermore, the birds given the diet with only the essential amino acid mixture did not consume their feed readily and had to be force-fed, an added indication of the inadequacy of this $\mathrm{N}$ supplement as the only source of $\mathrm{N}$.

In an earlier study from this laboratory (Wessels \& Fisher, 1965) considerable $\mathrm{N}$ retention had been observed on a diet supplemented with non-essential amino acids, whereas in the present study this was not so. We ascribe this difference, in part, to the younger age (less than $x$ year) of the cocks in the present study (2-year-old cocks were used in the earlier studies). Younger cocks are much leaner than older birds (Summers \& Fisher, I962) and thus would seem to be at a disadvantage, since the diet and the dietary $\mathrm{N}$ were fed on the basis of body-weight. That the older birds in our earlier studies with their greater amounts of body fat did indeed receive larger amounts of dietary $\mathrm{N} / \mathrm{g}$ muscle tissue was shown when we fed the diets of these older birds to another group of young cocks at a slightly higher concentration. Under these conditions the young cocks were also in positive $\mathrm{N}$ balance.

In part, the lower $\mathrm{N}$ retention observed in the present study, as compared with the earlier one (Wessels \& Fisher, 1965), was also due to the present inclusion of feather $\mathrm{N}$ and of biopsy tissue $\mathrm{N}$ in the total $\mathrm{N}$ balance. In the second experiment (Table 5 ) the exclusion of feather and biopsy tissue $N$ (which was not of metabolic origin, but was arbitrarily removed) would place the cocks receiving essential amino acids + aspartic acid into positive $\mathrm{N}$ balance.

Finally, although the concentrations of the $\mathrm{N}$ components of muscle were generally lower in the cocks receiving only the essential amino acid mixture than in those given the additional non-essential amino acid supplement, it should be stressed that in the former group, nevertheless, muscle concentrations of these components had essentially recovered to the levels found before depletion. This brings out the importance of the essential amino acids in replenishing the protein reserves and also suggests that the fluctuations in concentration of RNA and of certain enzymes with dietary protein supply may well be a controlling factor in the regulation of $\mathrm{N}$ losses and accretions during protein deficiency and sufficiency. The reduction during protein depletion of these muscle constituents would make a certain amount, albeit small, of amino acids available for other purposes. Through a reduction of RNA and of these enzymes, the rate of $\mathrm{N}$ catabolism would decrease, a suggestion supported by many studies from the early work of Folin (1905), who showed that human subjects on a protein-free diet first excrete $\mathrm{N}$ at a high rate followed by a rapid decrease. Conversely, with very high intakes of protein the rate of catabolism is increased beyond that observed on more moderate intakes (Vaughan, Filer \& Churella, i962). 


\section{REFERENCES}

Allison, J. B. \& Wannemacher, R. W. Jr (1965). Am. F. clin. Nutr. 16, 445.

Ashley, J. H. (1966). Protein depletion and repletion studies in adult cocks. Doctoral Dissertation, Rutgers-The State University, New Brunswick, N.J.

Basak, M. N. (1958). Indian \%. med. Res. 46, 307.

Ferrari, A. (1960). Ann. N.Y. Acad. Sci. 87, 792.

Fisher, H., Brush, M. K., Griminger, P. \& Sostman, E. R. (I965). F. Nutr. 87, 306.

Folin, O. (1905). Am. $\mathscr{F}$. Physiol. r3, I I7.

Kies, C., Williams, E. \& Fox, H. M. (I965). F. Nutr. 86, 350.

Leveille, G. A. \& Fisher, H. (1958). F. Nutr. 66, 44r.

Shapiro, R. \& Fisher, H. (1962). F. Nutr. 76, 106.

Sigma Chemical Co. St Louis, Missouri (1959). Sigma Technical Bulletin, no. 505.

Summers, J. D. \& Fisher, H. (1962). Z. Ernährungsw. 3, 48.

Vaughan, O. W. Filer, L. J. Jr \& Churella, H. (I962). Pediatrics, Springfield 29, 90.

Wessels, J. P. H. \& Fisher, H. (1965). Br. F. Nutr. r9, 57. 